\title{
Corporate Volunteering and Creating a Quality Culture
}

\author{
Martina MINÁROVÁ ${ }^{\text {, Ladislav MURA }}{ }^{2^{*}}$, Denisa MALÁ ${ }^{3}$
}

${ }^{1}$ Associate Professor Dr., PhD. in Economics, Faculty of Economics, Department of Corporate Economics and Management, Matej Bel University in Banská Bystrica, Slovakia E-mail: martina.minarova@umb.sk

${ }^{2}$ Associate Professor Dr., PhD. in Economics, Faculty of Economics and Business, Department of International

Entrepreneurship, Pan-European University in Bratislava, Slovakia E-mail: ladislav.mura@gmail.com

${ }^{3}$ Associate Professor Dr., PhD. in Management, Faculty of Economics, Department of Corporate Economics and Management, Matej Bel University in Banská Bystrica, Slovakia E-mail: denisa.mala@umb.sk

* Corresponding Author

\author{
Received: 09.07.2021 Accepted: 11.10.2021 Published: 01.12.2021 DOI: 10.47750/QAS/22.185.01
}

\begin{abstract}
The article deals with the analysis of the current state of corporate volunteering in Slovakia. The main aim is to identify and define the motives as well as the barriers to the development of corporate volunteering in Slovak enterprises. The analysis was based on data obtained from a questionnaire survey conducted among 195 enterprises with real experience with volunteering activities. For the purposes of the research and in order to ensure the representativeness of the sample, 350 correctly completed questionnaires were used. Simple mathematical and non parametric statistical methods (Chi-square test, Binomial test, Friedman test, Wilcoxon test) were used for data evaluation. The representativeness of the sample, according to the gender, was tested by the Chi-square test. Representativeness was confirmed. The results show that in Slovakia, volunteering is perceived as help for which no reward is expected, manual help predominates, mainly in the environmental area. There is a need to increase incentives, initiative and communication by the company management, which is very important for enhancing the interest of employees. We consider the results of the survey to be a source of knowledge for the area of management because volunteering is currently becoming a multidimensional phenomenon. The article brings important findings in the field of corporate volunteering, which are based on the practical experience of Slovak enterprises. The principle of sustainable corporate volunteering is a key factor in supporting the process of sustainable human development and the development of a corporate quality culture.
\end{abstract}

Keywords: corporate volunteering; volunteer; motivation; barriers; quality culture

\section{Introduction}

Alongside the dynamic development of the whole society, in every area of social life, we can also observe the development of human potential in recent years. The corporate volunteering is a way to acquire experience, knowledge, work habits and enhance professional skills, it is an opportunity to selfrealisation, make contacts and gain valuable experience. People have been always involved in the issue of volunteering, which was in the past based mainly on the help to poor, elderly, neglected, abandoned or orphans. The term "volunteer" comes from the Latin word voluntarius, which means "willing" or "disposed" (disposed to help). Employee volunteering is the act of providing time, knowledge and skills of the employee as part of community service, impacts or socially responsible activities often sponsored by companies without any further compensation or direct personal remuneration. (Bussell \& Forbes, 2008; Rodell, 2013; Hao et al., 2020; Prokopenko et al., 2020). More than $90 \%$ of Fortune Global 500 enterprises are actively involved in corporate volunteer programmes (Boccalandro, 2009). Volunteer programmes provide enterprises with many benefits. They increase the image and reputation of the brand (Loosemore \& Bridgeman, 2017; Plewa et al., 2015), improve the work productivity (Rodell, 2013; Rodell \& Lynch, 2016) and improve attitudes of the employees
(Breitsohl \& Ehrig, 2016; Haski-Leventhal et. al., 2019; Im \& Chung, 2018; Sekar \& Dyaram, 2017).

The research of corporate volunteering, which is the subject matter of this study, is based on the assessment of the motives and barriers to the development of corporate volunteering in Slovak enterprises. The research results were obtained by means of the statistical hypothesis testing methods. Based on the findings, recommendations were formulated for enterprises to ensure development and improvement of quality culture using corporate volunteering in Slovak enterprises.

\section{Literature review}

One of the applied and increasingly accentuated forms of human potential development is the corporate volunteering, which is still not given sufficient attention in scientific research circles, although the Universal Declaration on Volunteering was adopted in 1990 and amended by the Board of Directors of the International Association for Voluntary Efforts (IAVE), January 2001 in the Netherlands. Volunteering is therein defined as the fundamental building block of civil society (Hanuláková and Pročková, 2001). It brings into life the noblest aspirations of humanity - the desire for peace, freedom, opportunity, security and justice for all people. The term of corporate volunteering is not legally established in Slovak legislation. The law in Slovakia 
recognizes only the concept of volunteering for a natural person, which is also regulated by a specific law. From the point of view of the Labour Code, it is possible to distinguish three types of volunteering: employee volunteering in his free time, employee volunteering in his working time, corporate volunteering within the employer's project. In the case of corporate volunteering within the employer's project, the employer has relatively broad competencies to set the conditions (with/without wage compensation, number of days, etc.). The law does not oblige the employers to conclude special insurance in this regard; it is therefore up to them to decide. Within the framework of the contractual regulation, the consent of the employee is important (it can also be a part of the employment contract in a separate document), as well as the scope and conditions of volunteer work (employment contract, collective agreement or internal regulation).

In the current era of globalization and permanent changes, the world is becoming smaller, more interdependent and complex. Volunteering is undoubtedly a source of many benefits not only for the aid recipients but also for society as a whole. These benefits are visible is the economic and social as well as cultural and human area. This trend reflects in the business area in the form of implementation of new kinds of business models (Korauš et al., 2020), type of community, which instead of direct profit generation for the stakeholders, provides as consideration for participation in the community otherwise inaccessible benefits (Borocki et al., 2019). One of the factors that can contribute to building a quality culture is employee volunteering. Thanks to corporate volunteering, the company's values are naturally linked to the values of employees (Chovanova Supekova et al., 2020), and at the same time, their internal motivation, sense of meaning and a proactive approach through helping the others are developed. Moreover, volunteer activities support innovations in management and can bring new business contacts for the company as well as continuously build a culture of quality (Hajduová, 2015; Istianingsih, 2020). Thanks to corporate volunteering, a company can gain new customers as people become more and more interested in how companies approach important societal issues. The culture of quality in the company is one of the prerequisites that influence the participation of employees in volunteering activities (Kim \& Kim, 2016). A corporate quality culture is understood as a system of shared values and standards (Schein, 1992). It is often perceived as a resource through which employees learn to handle external issues. Employees integrate the corporate value system into their value system (Sabie et al., 2020). Employees show a positive response to activities that are aligned with the corporate value system. Li et al. (2015) claimed that conformity of values would probably raise the involvement of the employees. Similarly, Lee et al. (2013) state that if employees see a match between corporate cultures and volunteering activities, employees are more likely attracted by volunteer programmes. Chong (2009) also emphasizes that alignment of CSR activities with the corporate culture is important for better engagement of employees into volunteer programmes. Afkhami et al. (2019) noted that the corporate volunteering culture creates positive attitudes of employees towards volunteer activities. In terms of involvement of the employees ( $\mathrm{Li}$ et al., 2015), the concluded compatibility of corporate quality culture and volunteer activity facilitate better participation of employees in volunteering. On the contrary, when employees perceive that volunteering is not in line with the corporate quality culture, this could lead to disinterest and reduce their participation in volunteer programmes. The term corporate volunteering is referred to as a concept that combines the beneficial activities of the company with the support of employee volunteering (Nešporová \& Schmidt, 2005). Employers in large multinational enterprises in Slovakia have mostly a positive attitude towards volunteering. Either they even give employees the opportunity to volunteer, through company volunteer days or they motivate them to volunteer in their free time. In general, there are still few companies in Slovakia that really take into account whether the job seeker was involved or is actively engaged in volunteering However, the reality is (and people from multinational enterprises agree with it) that volunteering supports a chance to get a job. A survey among employers conducted by the Platform of volunteer centres and enterprises in cooperation with Matej Bel University in Banská Bystrica showed that for most of the interviewed employers, the skills and abilities that the applicants can acquire in their volunteer activities are important at the recruitment of an employee. Through volunteer activities, the company may only benefit. If a company decides to involve the employees in volunteer activities, it shows that it is not indifferent to the situation in society, improves its image and strengthens the brand loyalty (Plewa et al. 2015; Loosemore \& Bridgeman 2017) as well as improves the performance of employees (Rodell et al. 2017). It is also significant that the volunteer activity is one of the ways to contribute to the development of key competencies of the employees, which helps to strengthen the relationship of the employee with the company and so it leads to the strengthening of the employee loyalty. Gaining new contacts and possible penetration into new markets can only supplement the previous positive consequences. The mentioned facts are also based on researches Cone Communications Employee Engagement 2016, according to which $74 \%$ of employees are convinced that they are satisfied with their work more when they have the opportunity to work on projects with a positive social impact. Other research of United Health Group 2013 has also confirmed that $81 \%$ of corporate volunteers believe that volunteering is a key factor in strengthening and improving their relationships with colleagues (Chaloupková, 2019). Research conducted in 2017 provided an overview of the impact of volunteering on the acquisition of leadership skills. As many as $80 \%$ of employees think that thanks to active volunteering it is easier for them to acquire leadership skills (Deloitte Impact Survey, 2016). Internal communication about volunteer programmes raises employees' awareness of various aspects of volunteer programmes, which include the type of activities, goals, beneficiaries, and role of employees. An increased level of awareness through communication could draw employees' attention to volunteer programmes. Communication of companies about their agenda and CSR activities (Bhattacharya et al., 2008; Maignan \& Ferrell, 2004; Mallum, 2016; Androniceanu, 2019) and information on volunteer activities of enterprises (Presti, 2013) showed a greater impact on the attractiveness of employees to volunteering and their participation in volunteering. Malouf et al. (2016) state that there is a strong relationship between internal communication and active employee participation in volunteer programmes. OpokuDakwa et al. (2018) and Afkhami et al. (2019) claim that information support in the form of communication increases the level of awareness of employees. In addition to providing information on volunteer programmes, proper planning of volunteer programmes is essential for better employee participation. (Afkhami et al., 2019). Volunteer programme planning decides on the type of volunteering activity, target group, volunteer interests and reflects the corporate culture (Sekar \& Dyaram, 2017, 2020). In accordance with the theory of employee involvement (Schaufeli \& Bakker, 2004), it is likely that effort a company makes for planning and the concept of a volunteer programme will increase employee participation in volunteer programmes. Lee et al. (2013) argue that wellplanned and performed volunteer programmes help create a better impression of their effectiveness among employees. It also builds trust among employees to engage in volunteer programmes. Employees first assess the orientation of the 
company, check the purpose of volunteer activities, and only then decide how to invest their time in these activities. If employees do not identify the efforts of the company to design and plan volunteer activities, they are less likely to participate in volunteer programmes.

Based on the results of research, Dubcova et al. (2014) identified the main areas in which the benefits of volunteering at the level of companies and employees can be identified (Presentation of the company, strengthening its credibility, building a good name; Moral satisfaction and self-realization of employees; Teambuilding and building of employee loyalty; Personal development of employees and the development of their professional as well as "soft" skills; Opportunity for active recreation and change of activity). Krasnopolskaya (2016) brings interesting findings within the studied issue and based on the analysis of binary logical regression she demonstrates that employee participation in corporate volunteering is positively related to four forms of off-site involvement: informal volunteering, formal volunteering, formal monetary donations and informal monetary donations. Corporate volunteering leads to greater employee engagement in volunteering because trust in the company can transform into increased employee confidence in social institutions. Further, on she states that corporate volunteering brings employees new unexpected situations, puts them in different roles and positions that they have to deal with, and so they can change their life priorities and re-evaluate their value system. Corporate volunteering socializes employees to carry out volunteering, which increases the probability that they would incorporate volunteering into their personal activities. Corporate volunteering appears to be an effective mechanism for stimulating civic engagement and volunteering infrastructure in post-communist countries.

Based on theoretical background and empirical studies dedicated to the researched issue, the following hypotheses were formulated:

$\mathrm{H} 1$ : It is assumed that more than $3 / 4$ employees agree with the statement that it is necessary to engage in voluntary activities.

$\mathrm{H}$ 2: It is assumed that more women are involved in voluntary activities than men.

H3: It is assumed that the most important reason influencing employee's involvement in corporate volunteering is to be useful and to help others.

During testing hypotheses was used a significance level of 0.05. Methods for testing statistical hypotheses (Binomial test, Chi-square, Friedman test, Wilcoxon test, level agreement test) were used to evaluate the research results. An exact binomial test, also called the fractional test, was used to test the $\mathrm{H} 1$ hypothesis, testing the statistical hypothesis of the agreement of the proportion of the base set with the constant. It holds that the binomial distribution has the parameters $n$ and $\pi 0$, and if $x<(n-$ $x)$ and $p>\pi 0$ occur, the alternative hypothesis is: $\pi>\pi 0$.

Hypothesis $\mathrm{H} 2$ was verified by a test of the significance of the Spearman correlation coefficient. Correlation is a measure of the dependence between two or more variables. The correlation coefficient can range from -1 to +1 . A value of -1 represents the highest negative and +1 the highest positive correlation. A value of 0 indicates no correlation (Kaščáková, Nedel'ová, 2010). Using this coefficient, we also determined the dependence of respondents' answers to individual questions from the gender point of view. If the $p$-value is less than 0.05 between the characters, there is a correlation. If the value of the correlation coefficient is negative for gender, it means that women are those who agree more than men. If the $p$-value is higher than 0.05 , it means that the answers to the questions are independent of the individual criteria.

Friedman's test and Wilcoxon's test were used to evaluate the questions and test hypothesis $\mathrm{H} 3$. The Friedman test is a nonparametric alternative to one-way factor analysis of variance ANOVA for dependent selections. It is used to test for differences between groups if the measured dependent variable is ordinal. The Wilcoxon paired test is a nonparametric test analogous to the t-test of independence. Its strength (ability to reject the null hypothesis if it does not apply) is $3 / \pi$ (i.e. about $95 \%$ ) compared to the paired t-test, so it is just slightly weaker. However, there are situations where paired t-test cannot be used, e.g., when the data obviously do not come from a normal distribution or are not quantitative in nature.

The Wilcoxon test can be used in such cases. However, the test assumes the symmetry of the $X-Y$ distribution under the assumption of a null hypothesis. In the case of strong asymmetry, a simple sign non-parametric test (sign test) can be used, but it is much weaker. The Friedman test verifies the agreement of the medians for $k(k>2)$ characters with the same categories, so for $k$ dependent selections with the same range $\mathrm{n}$. The Wilcoxon (Mann-Whitney) test is stronger to verify the equality of distributions of two independent samples compared to the median test (Kaščáková, Nedel'ová, 2010).

\section{Methodology}

The main objective of the survey was to obtain an image of current employee volunteering in enterprises operating in the Slovak Republic and to summarize the knowledge for business management about the benefits of volunteering at the level of enterprises as well as employees themselves. We examined the motives and barriers to the application and development of employee volunteering in Slovak enterprises. 195 enterprises with real experience with volunteering activities took part in the survey. These were selected targeted and only those enterprises were addressed that have already been executing volunteer activities. The contact persons were usually managers in the area of human resources management. We asked them to fill the questionnaire by at least two employees. For the purposes of the research and in order to ensure the representativeness of the sample, 350 correctly completed questionnaires were used.. The results of the survey can provide feedback for the involved enterprises and at the same time, they are an inspiration for those who are still considering these activities. Due to its size and composition, the sample of enterprises cannot be considered statistically representative on a national economic scale, but in view of the fact that it included almost all business entities with real volunteer experience in Slovakia, we consider it relevant considering the objectives of the survey. An exploratory method - a questionnaire survey was used to map the situation in the studied field. To ensure direct contact with the respondents, the students of the Faculty of Economics of the MBU in Banská Bystrica carried out the data collection. The data collection was realised in the period from March 2019 to June 2019, after the agreement with the representatives of the enterprises, concentrated in the database and willing to participate in the survey in the form of personal contact. Simple mathematical and statistical methods were used for data evaluation. Mainly companies operating in the private sector participated in the survey that made up $70 \%$ of the sample, while nearly half of them were Limited companies. The major involvement of the companies from the private sector in comparison with only $11 \%$ share of public sector companies shows a significantly stronger potential of private enterprises to engage in this area. This is not surprising, as the private sector has more resources as well as opportunities to gain positive effects of engaging in volunteer activities. In terms of sector structure of the sample, the representation of the sector of services was more significant (32\% companies), other sectors were represented evenly. The size structure of companies was 


\section{GENERAL MANAGEMENT}

diverse. The sample included all size categories of enterprises, from micro $(25 \%)$, small with less than 50 employees, which accounted for $22 \%$, medium-sized (20\%), up to enterprises employing more than 1000 employees, which represented 33\% of the sample.

The study involved 171 men and 179 women. The representativeness of the sample, according to the gender, was tested by the Chi-square test. Representativeness was confirmed ( $p$-value $=0.983$ ).

Representativeness of the sample, according to gender, we tested the Chi-square test. The test statistic of the Chi-square test is formed by the sum of the raised differences between the observed $(\mathrm{O})$ and expected $(\mathrm{E})$ values divided by the expected frequency $(\mathrm{E})$ :

$$
\mathbf{x}^{2}=\sum_{\mathbf{i}=1}^{\mathrm{N}} \frac{(\mathbf{O} \mathbf{i}-\mathbf{E i})^{2}}{\mathrm{Ei}}
$$

Pearson's Chi-square test of good agreement is based on a frequency table and tests the statistical hypothesis that the abundances in individual categories are equal to the expected (theoretical) abundances (Kaščáková, Nedelová, 2010).

\section{Results and discussion}

The survey results have shown that the significantly predominant form of realisation of volunteer activities is manual help (physical activity), which is preferred by up to $72 \%$ of companies. Regarding the selection of specific activities for volunteering, up to half of the companies prefer those activities that are directly related to the region in which they operate, but are not related to their subject of business ( $89 \%$ of cases). Most companies (67\%) use events organized by other entities to participate in volunteer activities. Those companies that carry out volunteer activities within their subject of business, use mainly forms of longer-term support of the selected subject (lectures organized for other organizations and the public (29\%), lectures for primary and secondary school students (15\%), and mentoring $(7 \%)$ to a lesser extent. Volunteer activities are more often carried out within the working hours of employees $(74.5 \%)$, but they also take place in their free time (49.3\%). In some companies, however, there is an overlap of working and nonworking time at the realisation of volunteer activities. As Jabbour et al. (2015) state, at present, it is necessary to support environmental management by creating a quality culture through supporting volunteer programmes. Some EU programmes support these activities (Kováčik and Imrovič, 2019). From the results of our survey we can state that in companies that perform corporate volunteering, they support the trend. The most represented areas of volunteering were the environmental (31\%) and sports area (27\%). As part of ecological activities, they reported the help at planting trees, mowing meadows, raking grass, landscaping, cleaning watercourses and their surroundings, visiting shelters, waste collection and its subsequent sorting, etc. In terms of the sports area, the respondents most often mentioned the organizing of a sports event or assistance at its organization. These were followed by the social area $(21 \%)$. The most frequent volunteer activities include the visits of children's homes and organizing a collection of clothes for the socially disadvantaged. Culture $(15 \%)$ was the fourth most represented area. Out of the volunteer activities in the area of culture, respondents indicated mainly the help at reconstruction work of cultural monuments, castles, assistance at organizing cultural events, cleaning of the facades from inscriptions, help in creative workshops and others. $6 \%$ of respondents noted volunteering in the educational area. The educational area was followed by the humanitarian and health volunteer activities, while both achieved the $4 \%$ share. Respondents most often reported they helped the drug addicts, assisted children in hospitals, helped disabled patients, and participated in mass blood donations. In the area of humanitarian volunteer aid, assistance to the homeless was most frequently mentioned. Another question we asked the respondents was about the feelings associated with volunteering. The majority of responses were associated with positive feelings $(91 \%)$ and that they were willing to participate in other activities. People need motivation to dedicate their free time and energy for others (Tab. 1.)

\begin{tabular}{|c|c|c|c|c|c|}
\hline \multicolumn{6}{|c|}{ q10a entertaiment } \\
\hline & & Frequency & Percent & Valid Percent & Cumulative Percent \\
\hline Valid & 1 & 5 & 1,4 & 100,0 & 100,0 \\
\hline Missing & System & 345 & 98,6 & & \\
\hline \multicolumn{2}{|l|}{ Total } & 350 & 100,0 & & \\
\hline \multicolumn{6}{|c|}{ q10b help to other people } \\
\hline & & Frequency & Percent & Valid Percent & Cumulative Percent \\
\hline Valid & 1 & 213 & 60,9 & 100,0 & 100,0 \\
\hline Missing & System & 137 & 39,1 & & \\
\hline \multicolumn{2}{|l|}{ Total } & 350 & 100,0 & & \\
\hline \multicolumn{6}{|c|}{ q10c praise of the employer } \\
\hline & & Frequency & Percent & Valid Percent & Cumulative Percent \\
\hline Valid & 1 & 12 & 3,4 & 100,0 & 100,0 \\
\hline Missing & System & 338 & 96,6 & & \\
\hline \multicolumn{2}{|l|}{ Total } & 350 & 100,0 & & \\
\hline \multicolumn{6}{|c|}{ q10d possibility to decide on the choice of the help receivers } \\
\hline & & Frequency & Percent & Valid Percent & Cumulative Percent \\
\hline Valid & 1 & 137 & 39,1 & 100,0 & 100,0 \\
\hline Missing & System & 213 & 60,9 & & \\
\hline \multicolumn{2}{|l|}{ Total } & 350 & 100,0 & & \\
\hline \multicolumn{6}{|c|}{ q10e good feeling / feeling of pride } \\
\hline
\end{tabular}




\section{GENERAL MANAGEMENT}

\begin{tabular}{|c|c|c|c|c|c|}
\hline & & Frequency & Percent & Valid Percent & Cumulative Percent \\
\hline Valid & 1 & 215 & 61,4 & 100,0 & 100,0 \\
\hline Missing & System & 135 & 38,6 & & \\
\hline \multicolumn{2}{|l|}{ Total } & 350 & 100,0 & & \\
\hline \multicolumn{6}{|c|}{ q10f meeting new people } \\
\hline & & Frequency & Percent & Valid Percent & Cumulative Percent \\
\hline Valid & 1 & 200 & 57,1 & 100,0 & 100,0 \\
\hline Missing & System & 150 & 42,9 & & \\
\hline \multicolumn{2}{|l|}{ Total } & 350 & 100,0 & & \\
\hline \multicolumn{6}{|c|}{ q10g followed by new experience } \\
\hline & & Frequency & Percent & \begin{tabular}{|l|} 
Valid Percent \\
\end{tabular} & Cumulative Percent \\
\hline Valid & 1 & 201 & 57,4 & 100,0 & 100,0 \\
\hline Missing & System & 149 & 42,6 & & \\
\hline \multicolumn{2}{|l|}{ Total } & 350 & 100,0 & & \\
\hline \multicolumn{6}{|c|}{ q10h competence development } \\
\hline & & Frequency & Percent & Valid Percent & Cumulative Percent \\
\hline Valid & 1 & 8 & 2,3 & 100,0 & 100,0 \\
\hline Missing & System & 342 & 97,7 & & \\
\hline \multicolumn{2}{|l|}{ Total } & 350 & 100,0 & & \\
\hline
\end{tabular}

Table 1: Motivation factors to participate in volunteering activities

Source: Own processing based on IBM SPPS output 19

Based on the answers we can claim that it is the effort to help other people and good feeling or feeling of pride that motivate most to participate in volunteering, which was reported by $61 \%$ respondents, followed by new experience and meeting new people $(57 \%)$ as well as the possibility to decide on the choice of the help receivers (39\%). According to our analysis, the least motivating factor is the praise of the employer (only $3.5 \%$ ). The fact that people care least about praise from the employer shows that their empathy for people they help is real.

As Dubcová et al. (2014) states, if companies care about implementing volunteering as part of their culture, penetrating its symbols and values, it is appropriate to support this by motivating employees to participate and then providing feedback in an appropriate form. Based on the available results of the research in the field of the formation of corporate cultures, employees are most often the source of impulses for innovation. Both top and line business managers' play an important role here. We also found out whether the respondents are associated with the benefits of volunteering. They reported that the biggest advantage the volunteering brings is that volunteering strengthens the relationships between employees $(33.10 \%)$. We evaluate the result positively and it also confirms the results of the research of the Health and Volunteering Study, United Health Group (2013), where $81 \%$ of corporate volunteers believe that volunteering is a key factor in strengthening and improving their relationships with colleagues (Chaloupková, 2019). The second most frequently chosen advantage of corporate volunteering is the creation of a positive corporate culture $(26.9 \%)$, followed by an advantage defined as "the opportunity to use their skills and potential outside of professional activities and responsibilities" (22,7\%). The findings correspond with the statements of the authors Lee et al. (2013); Li et al. (2015), who found out those employees, are attracted more by volunteer programmes if they see a concordance between the corporate quality culture, declared corporate values and volunteer activity. Another significant advantage for employees is also the acquisition of leadership skills, which was started by $20 \%$ of respondents. We assume that targeted selection of volunteering activities could improve employee leadership skills, as evidenced by the results of Deloitte's research (2016), where up to $80 \%$ of employees believe that it is easier to acquire leadership skills through active volunteering. The incentive for the implementation of volunteering comes from the management of the company $(65.6 \%)$, but to a significant extent, the initiative is also on the side of the employees themselves $(63.2 \%)$, which points to their engagement in this issue and the company management provides them with a relatively wide space. Many companies reported simultaneously both sources of incentives for volunteering. We cannot determine a significant predominance of management in the issue of initial activity for volunteer activities. As the results of the research of Sekar \& Dyaram (2017) confirm, in the support of volunteering, the initiative and support of top management is very important to increase the participation of employees in corporate volunteering. We evaluate positively the considerable interest of employees in this area. $61 \%$ of respondents answered positively on the question of whether the employer was interested in their volunteer activities at the job interview. Therefore, it is obvious that employers are beginning to give sufficient weight to the volunteer activities of their potential employees. They are aware of the necessity to involve socially beneficial activities in their strategy, which can mean a significant competitive disadvantage for those companies that do not perform these activities. We also examined how volunteering is declared in the documentation of the companies. Out of the total number of respondents, $71 \%$ stated that they have declared volunteer activities in the written form. The results of the survey show that if companies decide to declare their volunteer documents in writing, it is most often in the responsible business strategy $(42 \%)$, in the code of ethics $(39.8 \%)$ or they have their own employee volunteering programme $(18.2 \%)$. $29 \%$ of respondents declared the form of non-formalized documents. We do not perceive the written formalization of volunteering policy as a necessary condition for the implementation of successful volunteering, but we recommend it as one of the prerequisites for the permanent orientation of activities in the field of volunteering. Our arguments also agree with the authors (Bhattacharya et al., 2008; Maignan \& Ferrell, 


\section{GENERAL MANAGEMENT}

2004; Mallum, 2016), who state that the agenda related to volunteering, activity planning, and information sharing demonstrate a greater impact on attractiveness for the employees to volunteer and their participation in volunteering. Regarding the planning, provision and implementation of volunteering activities, this falls within the competences of the HR department $(44 \%)$ and the marketing department $(23 \%)$. Only $12 \%$ of respondents said that there is a person in the company who is engaged in volunteering activities as well as internal communication in this area, which was evaluated very positively. Less than one-third of respondents (21\%) stated that they organize volunteer activities individually. For the objective assessment of the researched issues, we found out what are the barriers at or for the realisation of volunteer activities. We examined it through an open question on this topic. Based on the results we can claim that respondents most often stated a lack of time for organizing volunteer activities. Negative experiences with volunteering and distrust of subjects are subsequently reflected in less frequent decisions to carry out volunteering activities. The lack of interest of the younger generation in manual work and insufficient promotion of volunteering are also the most cited barriers.

We focused the survey on the degree of agreement with the statement that it is necessary to engage in corporate volunteering. $21.1 \%$ of respondents strongly agree with this statement, $59.4 \%$ agree, $3.4 \%$ disagree and $16 \%$ cannot express themselves. After excluding respondents who could not express themselves and after divided into two groups - those who agree and those who disagree, we confirmed the hypothesis $\mathrm{H} 1$ ( $\mathrm{p}$-value $=0$ ) by a binomial test. We accept the hypothesis that more than $3 / 4$ employees agree with the statement that it is truly important to engage in voluntary activities (Tab. 3.). Gallup performed a meta-analysis across 199 studies covering 152 organizations, 44 industries, and 26 countries. They discovered that for companies where employees were more engaged in voluntary activities than not, their profitability jumped by $16 \%$. Not only that, general productivity was $18 \%$ higher than other companies. Customer loyalty was $12 \%$ higher and quality jumped up by an incredible 60\% (Merchant, 2011).

\begin{tabular}{|c|c|c|c|c|c|c|}
\hline \multicolumn{7}{|c|}{ Binomial Test } \\
\hline & & Category & $\mathrm{N}$ & Observed Prop. & Test Prop. & Exact Sig. (2-tailed) \\
\hline \multirow[t]{3}{*}{$\mathrm{H} 1$} & Group 1 & 1,00 & 282 & ,96 & ,75 &, 000 \\
\hline & Group 2 &, 00 & 12 & ,04 & & \\
\hline & Total & & 294 & 1,00 & & \\
\hline
\end{tabular}

Table 2: Binomial test hypothesis $\mathrm{H1}$

Source: Own processing based on IBM SPPS output 19

$\mathrm{H} 2$ : It is assumed that more women than men are involved in voluntary activities.

In the survey, we found out whether employees are involved in volunteer activities. Exactly $73.4 \%$ of respondents participate in voluntary activities and $26.6 \%$ stated that they have not participated in these activities yet. Hypothesis $\mathrm{H} 2$ is also related to the evaluation of the researched question, in which we assume that more women than men are involved in volunteer activities. By testing the agreement of the Spearman rank correlation coefficient, it was found that the answers to the question are independent of gender ( $p$-value $=0.067$ ). Based on this, we reject hypothesis $\mathrm{H} 2$. We state that in Slovakia there are no gender differences to volunteer. As the results of the secondary research of Einolf (2010) sex differences in the amount of volunteering vary from country to country, supporting the view that these differences have a social, not a biological, basis. For example, in Australia, the United Kingdom, Japan, the
Netherlands, and Italy, women are more likely to volunteer than men, but in Canada there are no gender differences and in Sweden, men are more likely to volunteer.

H3: It is assumed that the most important reason influencing employee involvement in corporate volunteering is to be useful and to help others.

As part of the survey, we verified the most common reasons for employee involvement in corporate volunteer activities. Seven activities were presented to the respondents (a. Increase the image of the company, b. Meet new friends and people, c. Be helpful and to help, d. Gain new experiences, do something other than at work, e. Interested in learning something and to gain new skills, f. Praise from superior, g. Meet new groups of people (marginalized groups, handicapped) Respondents had to mark a maximum of 3 options. Friedman's test (Tab. 4.) confirmed that the activities are not equally significant ( $p$-value $=0)$.

\begin{tabular}{|l|l|}
\hline \multicolumn{2}{|l|}{ Test Statistics $^{\text {a }}$} \\
\hline N & 350 \\
\hline Chi-Square & 547,444 \\
\hline df & 7 \\
\hline Asymp. Sig. &, 000 \\
\hline a. Friedman Test \\
\hline
\end{tabular}

Table 3: Friedman's test of the reasons for employee's involvement in corporate volunteering

Using the Wilcoxon sign test (Tab. 4.), we determined the order of significance of the individual activities. 


\section{GENERAL MANAGEMENT}

\begin{tabular}{|c|c|c|c|c|c|c|c|}
\hline \multicolumn{8}{|c|}{ Test Statistics $^{\text {b }}$} \\
\hline & $016^{e}-016^{c}$ & $016^{d}-016^{e}$ & $016^{b}-016^{d}$ & $016 \mathrm{~g}-016 \mathrm{~b}$ & $016^{a}-016^{g}$ & $016^{h}-016^{a}$ & $016^{f}-016^{h}$ \\
\hline Z & $-4,042^{\mathrm{a}}$ &,$- 243^{a}$ & $-6,266^{a}$ & $-2,293^{a}$ & $-2,662^{a}$ &,$- 480^{a}$ &,$-- 708^{a}$ \\
\hline $\begin{array}{l}\text { Asymp. } \\
\text { Sig. (2- } \\
\text { tailed) }\end{array}$ & ,000 & ,807 &, 000 & ,022 & ,008 & ,631 & ,480 \\
\hline
\end{tabular}

Table 4: Wilcoxon's test of the reasons for employee's involvement in corporate volunteering

Source: Own processing based on IBM SPPS output 19

The most frequently identified reason why employees involve in corporate volunteering is definitely to be helpful and to help others. Based on this finding, we accept hypothesis $\mathrm{H} 3$. Research (Breitsohl \& Ehrig, 2016; Dubcová et al., 2014; Im \& Chung, 2018, Merchant, 2011, Sekar \& Dyaram, 2020) has confirmed that helping others is one of the most common reasons for volunteering. As Runte \& Basil (2011) also found out that employees were most motivated to involve in corporate volunteering by their desire to help, escape from their own problems, gaining knowledge, feeling good and making social contacts.

Often referred was also interest in learning something and gaining new skills as well as to have new experiences, doing something different than at work. Then meet new friends and people and then meet marginalized groups and handicapped people. The least mentioned reasons were to increase the company's image and gain praise from a superior. Using a level match test, we found that being useful and helping others as the reason that respondents identified as the most important reason for involving in corporate volunteering activities is independent of their gender ( $p$-value $=0.49)$. Women involve in corporate volunteering because they want to meet new groups of people who need help $(p$-value $=0.030, r=-0.116)$.

\section{Conclusions}

Based on the results of our survey, we can state that the involvement of enterprises in volunteering and the interest of employees in Slovakia are gradually increasing. The majority of responses were associated with positive feelings (91\%) and they indicated a willingness to participate in other activities. It is necessary to support the volunteering, as it creates opportunities for the development of collegiality (33\%), empathy $(62 \%)$, the development of leadership skills $(80 \%)$ and the development of human potential in general. Nevertheless, there is no predominant degree of involvement on the part of the company's management (66\%). It is essential to integrate the corporate volunteering into the long-term strategic plan of each company, as well as longstanding creating of brand and image. It actually affects all activities in the company - increases its scope and efficiency, adds value and helps build a culture of quality. The sooner other companies in Slovakia realize the meaningfulness of volunteering activities, the sooner they will gain a competitive advantage. Of course, volunteering should not be done just for a better image. Primarily, it is an expression of a sincere effort to help in any area. Volunteering brings great benefits but also challenges for enterprises in Slovakia. The results of the research can serve as an incentive for further examination of the issue. In further research, we recommend focusing on the extent to which corporate volunteering programmes affect perceptions of image and reputation by the consumers. To compare job satisfaction, engagement and work commitment between active volunteers and those employees who participate only occasionally or at all in volunteer programmes.

\section{Acknowledgments}

This work has been supported by the project VEGA $1 / 0318 / 19$ Behavioural aspects of quality and their impact on creating a quality culture and by the project VEGA 1/0813/19 Managing the development of innovative and start-up forms of businesses in international environment and verification of INMARK concept, which has received funding from the Ministry of Education, Science, Research and Sport of the Slovak Republic.

\section{References}

[1] Androniceanu, A. (2019). Social Responsibility, an Essential Strategic Option for a Sustainable Development in the Field of BioEconomy. Www.amfiteatrueconomic.ro, 21(52), 503. doi:10.24818/ea/2019/52/503

[2] Bhattacharya, C.B., Sen, S. \& Korschun, D. (2008). Using corporate social responsibility to win war for talent. MIT Sloan Management Review, 49(2), 1-10

[3] Boccalandro, B. (2009). Mapping Success in Employee Volunteering: The Drivers of Effectiveness for Employee Volunteering and Giving Programs and Fortune 500 Performance. Chestnut Hill: Boston College Center for Corporate Citizenship, 52

[4] Borocki, J., Radisic, M., Sroka, W., Greblikaite, J., \& Androniceanu, A. (2019). Methodology for Strategic Posture Determination of SMEs. Engineering Economics, 30(3), 265-277. doi:10.5755/j01.ee.30.3.21966

[5] Breitsohl, H., \& Ehrig, N. (2016). Commitment through Employee Volunteering: Accounting for the Motives of Inter-Organisational Volunteers. Applied Psychology, 66(2), 260-289. doi:10.1111/apps.12092

[6] Bussell, H., \& Forbes, D. (2008). How UK universities engage with their local communities: a study of employer supported volunteering. International Journal of Nonprofit and Voluntary Sector Marketing, 13(4), 363-378. doi:10.1002/nvsm.331

[7] Chaloupková, M. (2019). Ako začat's firemným dobrovol'níctvom. Available at: https://www.nadaciapontis.sk [Accessed 20 Oct. 2020].

[8] Chong, M. (2009). Employee Participation in CSR and Corporate Identity: Insights from a Disaster-Response Program in the AsiaPacific. Corporate Reputation Review, 12(2), 106-119. doi:10.1057/crr.2009.8

[9] Chovanova Supekova, S., Krchova, H. \& Zbranek, P. (2020). Influence of the gender of the project managers on the application of csr standards in project management of Slovak companies. 13th International Scientific Conference on Reproduction of Human Capital - Mutual Links and Connection (RELIK), RELIK 
2020: reproduction of human capital - mutual links and connections, 188-197

[10] Deloitte. (2016). Building leadership skills through volunteerism. Available at: https://www2.deloitte.com [Accessed 12 Nov. 2020].

[11] [11] Dubcová, G., Joniaková, Z. \& Blštáková, J. (2014). Employees'volunteering - Applied corporate social responsibility in Slovak business economy. Ekonomika a management, 3, 1-13

[12] Einolf, C. J. (2010). Gender Differences in the Correlates of Volunteering and Charitable Giving. Nonprofit and Voluntary Sector Quarterly, 40(6), 1092-1112. doi:10.1177/0899764010385949

[13] Hajduová, Z., Lacko, R., Mildeová, S., \& Stričík, M. (2015). Case Study In The Field Of Innovation In Selected Companies In Slovak Republic. Annals of the Alexandru Ioan Cuza University Economics, 62(1), 103-119. doi:10.1515/aicue-2015-0008

[14] Hanuláková, E., \& Pročková, A. (2001). Societal marketing - The contemporary marketing concept. Ekonomicky casopis, 49(6), 1113-1133

[15] Hao, J., Li, C., Yuan, R., Ahmed, M., Khan, M. A., \& Oláh, J. (2020). The Influence of the Knowledge-Based Network Structure Hole on Enterprise Innovation Performance: The Threshold Effect of R\&D Investment Intensity. Sustainability, 12(15), 6155. doi:10.3390/su12156155

[16] Haski-Leventhal, D., Kach, A., \& Pournader, M. (2019). Employee Need Satisfaction and Positive Workplace Outcomes: The Role of Corporate Volunteering. Nonprofit and Voluntary Sector Quarterly, 48(3), 593-615. doi:10.1177/0899764019829829

[17] Im, S., \& Chung, Y. (2018). Employee Volunteering Meaningfulness and Organizational Citizenship Behavior: Exploring the Effects of Organizational Support, Pride, and Trust. Sustainability, 10(12), 4835. doi:10.3390/su10124835

[18] ISTIANINGSIH, N., MASNUN, A., \& PRATIWI, W. (2020). Managerial performance models through decision making and emotional intelligence in public sector. ADMINISTRATIE SI MANAGEMENT PUBLIC, 1(35), 153-166. doi:10.24818/amp/2020.35-10

[19] Jabbour, C. J. C., Jugend, D., Jabbour, A. B. L. de S., Gunasekaran, A., \& Latan, H. (2015). Green product development and performance of Brazilian firms: measuring the role of human and technical aspects. Journal of Cleaner Production, 87, 442451. doi:10.1016/j.jclepro.2014.09.036

[20] Kaščáková, A., \& Nedel'ová, G. (2010). Štatistické metódy pre spoločenské a humanitné vedy. Banska Bystrica : Univerzita Mateja Bela, 72.

[21] Kim, J., \& Kim, T. (2014). Multi-level Antecedents of Company Support for Employee Volunteering. Corporate Social Responsibility and Environmental Management, 23(1), 37-49. doi:10.1002/csr.1360

[22] Korauš, A., Havierniková, K., Gombár, M., Černák, F., \& Felcan, M. (2020). Dimensions and their elements affecting the innovative activities of agricultural SMEs toward their sustainable development. Entrepreneurship and Sustainability Issues, 8(2), 1142-1157. doi:10.9770/jesi.2020.8.2(68)

[23] Kováčik, V., \& Imrovič, M. (2019). Implementation of the EU Operational Program Employment and Social Inclusion in the Slovak Republic in the Context of Selected Social Indicators. OnLine Journal Modelling the New Europe, (30), 23-42. doi:10.24193/ojmne.2019.30.02

[24] Krasnopolskaya, I., Roza, L., \& Meijs, L. C. P. M. (2015). The Relationship Between Corporate Volunteering and Employee Civic Engagement Outside the Workplace in Russia. VOLUNTAS: International Journal of Voluntary and Nonprofit Organizations, 27(2), 640-672. doi:10.1007/s11266-015-9599-6

[25] Lee, E. M., Park, S.-Y., \& Lee, H. J. (2013). Employee perception of CSR activities: Its antecedents and consequences. Journal of Business Research, 66(10), 1716-1724. doi:10.1016/j.jbusres.2012.11.008

[26] Li, M., Wang, Z., You, X., \& Gao, J. (2015). Value congruence and teachers' work engagement: The mediating role of autonomous and controlled motivation. Personality and Individual Differences,
80, 113-118. doi:10.1016/j.paid.2015.02.021

[27] Loosemore, M., \& Bridgeman, J. (2017). Corporate volunteering in the construction industry: motivations, costs and benefits. Construction Management and Economics, 35(10), 641-653. doi:10.1080/01446193.2017.1315150

[28] Maignan, I., \& Ferrell, O. C. (2004). Corporate Social Responsibility and Marketing: An Integrative Framework. Journal of the Academy of Marketing Science, 32(1), 3-19. doi:10.1177/0092070303258971

[29] Mallum, K. (2016). Volunteers/Volunteering. The International Encyclopedia of Organizational Communication, 2-14. doi:10.1002/9781118955567.wbieoc217

[30] Malouf, A., Selaković, M., \& Ljepava, N. (2016). Exploring the Relationship Between Corporate Volunteering and Internal Communications in Multinational Organizations. Communication Management Review, 1(2), 6-22. doi:10.22522/cmr20160208

[31] Merchant, N. (2011). People are not cogs. Harvard business review, 6, 1-11.

[32] Nešporová, M., \& Schmidt, H. L. (2005). Firemní dobrovolnictví. In: Kolektiv autoru. Napříc společenskou odpovedností firem. Praha: AISIS, $46-54$

[33] Opoku-Dakwa, A., Chen, C. C., \& Rupp, D. E. (2018). CSR initiative characteristics and employee engagement: An impactbased perspective. Journal of Organizational Behavior, 39(5), 580-593. doi:10.1002/job.2281

[34] Plewa, C., Conduit, J., Quester, P. G., \& Johnson, C. (2014). The Impact of Corporate Volunteering on CSR Image: A Consumer Perspective. Journal of Business Ethics, 127(3), 643-659. doi:10.1007/s10551-014-2066-2

[35] Lo Presti, A. (2012). The Interactive Effects of Job Resources and Motivations to Volunteer Among a Sample of Italian Volunteers. VOLUNTAS: International Journal of Voluntary and Nonprofit Organizations, 24(4), 969-985. doi:10.1007/s11266-012-9288-7

[36] Prokopenko, O., Osadchenko, I., Braslavska, O., Malyshevska, I., Pichkur, M., \& Tyshchenko, V. (2020). Competence approach in future specialist skills development. International Journal of Management, 11(4), 651. DOI: 10.34218/IJM.11.4.2020.062

[37] Rodell, J. B., \& Lynch, J. W. (2016). Perceptions of Employee Volunteering: Is It "Credited" or "Stigmatized" by Colleagues? Academy of Management Journal, 59(2), 611-635. doi:10.5465/amj.2013.0566

[38] Rodell, J. B., Booth, J. E., Lynch, J. W., \& Zipay, K. P. (2017). Corporate Volunteering Climate: Mobilizing Employee Passion for Societal Causes and Inspiring Future Charitable Action. Academy of Management Journal, 60(5), 1662-1681. doi:10.5465/amj.2015.0726

[39] Runte, M., \& Basil, D. Z. (2011). Personal and corporate volunteerism: employee motivations. International Journal of Business Environment, 4(2), 133. doi:10.1504/ijbe.2011.040171

[40] SABIE, O. M., PÎRVU, C., BURCEA, Ștefan G., BRISSCARIU, R. M., \& APOSTOL (VOICU), S. A. (2020). The influence of emotional intelligence on employee's performance: a case from Romania's public sector. ADMINISTRATIE SI MANAGEMENT PUBLIC, 1(35), 40-57. doi:10.24818/amp/2020.35-03

[41] Schaufeli, W. B., \& Bakker, A. B. (2004). Job demands, job resources, and their relationship with burnout and engagement: a multi-sample study. Journal of Organizational Behavior, 25(3), 293-315. doi:10.1002/job.248

[42] Schein, E. H. (1992). Organizational Culture and Leadership. San Francisco: Jossey Bass Publishers, 418

[43] Sekar, S., \& Dyaram, L. (2017). What drives employees to participate in corporate volunteering programs? Social Responsibility Journal, 13(4), 661-677. doi:10.1108/srj-06-20170097

[44] Sekar, S., \& Dyaram, L. (2020). What makes employees participate in volunteering programs? The role of organizational support. International Journal of Organizational Analysis, 29(2), 512-528. doi:10.1108/ijoa-11-2019-1939 